\section{International Scientific Journal Theoretical \& Applied Science}

\author{
p-ISSN: 2308-4944 (print) e-ISSN: 2409-0085 (online) \\ Year: $2016 \quad$ Issue: 4 Volume: 36 \\ Published: $30.04 .2016 \quad$ http://T-Science.org
}

Elnur Latif oglu Hasanov Corresponding member of International Academy of Theoretical and Applied Sciences, Ph.D., Senior specialist of Ganja Department Azerbaijan National Academy of Sciences,

Ganja, Azerbaijan 1-hasan@hotmail.com

SECTION 12. Geology. Anthropology.

Archaeology.

\title{
ABOUT RESEARCH OF SOME FEATURES OF HISTORICAL- CULTURAL PAST OF GANJA FOR THE RENAISSANCE PERIOD
}

Abstract: On the basis of the heritage of the genius thinker and poet Nizami Ganjavi have been investigated the basic features of historic-cultural past of Ganja city as the main sample of multiculturalism in this scientific work.

Key words: Ganja, Azerbaijan, historical-ethnographic research, Nizami Ganjavi.

Language: Russian

Citation: Hasanov EL (2016) ABOUT RESEARCH OF SOME FEATURES OF HISTORICAL-CULTURAL PAST OF GANJA FOR THE RENAISSANCE PERIOD. ISJ Theoretical \& Applied Science, 04 (36): 13-20.

Soi: http://s-o-i.org/1.1/TAS-04-36-2 Doi: crossef http://dx.doi.org/10.15863/TAS.2016.04.36.2

\section{ОБ ИССЛЕДОВАНИИ НЕКОТОРЫХ ОСОБЕННОСТЕЙ ИСТОРИКО-КУЛЬТУРНОГО ПРОШЛОГО ГЯНДЖИ В ПЕРИОД ВОЗРОЖДЕНИЯ}

Аннотация: В данной научной работе были исследованы основные черты историко-культурного прошлого Гянджи на основе наследия великого мыслителя и поэта Низами Гянджеви как важного образца мультикультурализма.

ключевые слова: Гянджа, Азербайджан, историко-этнографическое исследование, Низами Гянджеви.

\section{Introduction}

Несмотря на то, что исследователи поэтического наследия Низами Гянджеви занимались изучением его жизни и деятельности, однако до сих пор осталось множество проблем, подлежащих глубокому и всестороннему анализу. Одной из таких областей в творчестве Низами Гянджеви являются проблемы стилистики и поэтики его маснави-поэм, составляющих «Пятерицу» («Хамсэ»).

Касыды, как известно, писались на самые разные темы. Существуют касыды политического, философского, социального, богословского содержания. Согласно мнению д. ф. н. Н. Араслы, «Низами сочинил много лирических стихов, но в религиозно-официальной части пяти маснави-поэм имеются различные виды касыды: «мадхиййа», «фахриййа» (самовосхваление»), «марсия» (элегии), «бахариййа» (посвященные весенному сезону), «шитабиййа» (посвященные зиме), «хазаниййа» (посвященные осени), где описывается природа в различные времена года. Они доказывают успешность поэта в сочинении касыд» [12, 14-15].
Низами в «Сокровищнице тайн» в тех главах, где воспевает и восхваляет пророка мусульман Мухаммеда, упоминает также о его предшественниках - пророках.

«Низами - правоверный мусульманин. Причем, не слепо верующий, а глубоко осве -домленный в теологии и философии ислама. Религиозные размышления его заключены, прежде всего, во вводных страницах поэм «Хамсе». Все они, по общей традиции, предваряются вос -певанием «всемилостивейшего и милосердного Аллаха», затем следует славословие пророку Му -хаммеду, повествование о его “мирадж”е - восхождении к Творцу».

В «Сокровищнице тайн» Низами намекает на коранический рассказ о сотворении человека (Адама) из глины, праха Всевышним и Всемогущим Аллахом (сура 38/70-85); в дву - стишиях, где упоминается антропоним (личное имя) Адам, содержится также намек на предание об изгнании его из рая за нарушение им запрета (сура 2/33-38); имя неоднократно участвует в качестве «талмих» (аллюзия): 
آدم از آن دانه كه شد هيضه دار توبيه شدش كلشكر خوشئوار

Для Адама, который съев то зерно, заболел поносом Раскаяние стало удобоваримым розовым вареньем.

В данном бейте содержится намек на предание: «Вдохнув в Адама жизнь, Аллах научил его именам всех вещей и этим возвысил его над ангелами, которым было приказано пасть перед человеком ниц. Ангел по имени Иблис отказался и был за это, низвергнут с небес на землю. Адам жил в небесном саду - раю вместе с сотворенной для него супругой. Они имели там все, чего только могли пожелать, но им, было, запрещено есть плоды с одного из райских деревьев. Иблис сумел проникнуть в райский сад и убедить Адама и его жену, что плоды этого дерева дадут им вечную жизнь и могущество. Соблазнившись, они нарушили запрет Аллаха, поели плодов, впер -вые ощутили свою наготу, которой застыдились, а затем были в наказание низвергнуты на землю, где обречены, жить и трудиться они и их потомки» (К. 2,30 (28-38) $36 ; 7,10(9-25) 34 ; 15: 26-36 ; 17: 61$ (63;18:50) 48,20.115 $(114-124) »[23,13]$.

«Поэт, исходя из требований свойственного ему стиля, часть художественно-изобразительных средств создал на основе слов, выражений, стихов (аят) и идей, истекающих из священного Корана, из коранических изречений. Во всех поэмах Низами можно обнаружить эффективные формы таких поэтических средств как «талмих» (аллюзия), намек, «иктибас» (заимствование)» [17, 54-55]

Далее:

$$
\text { توبة دل در جمنش بوي تست كوي تست }
$$

Сердечное покаяние на лугу его (естество) - твой аромат,

А розовое варенье для него прах у твоей обители.

$$
\text { دل زلشكر از كلشكري تلشكر توبه كورد }
$$

Когда сердце вкусило твое розовое варенье раскаяния,

Розовое варенье отреклось (называться) розовым вареньем».

В данном отрывке, как видно, поэт, используя стилистическую фигуру «талмих», намекает на коранический рассказ о раскаянии (توبة ) Адама. «В Коране сказано, что Бог создал тело из глины, а душу из огня. Все ангелы признали новое творение, один Эблис отказался и был изгнан из рая, где поселился Адам. В раю была создана Ева. Эблис из мести соблазнил первых людей, и они были сброшены на землю. Бог сжалился над раскаявшимся Адамом и послал архангела Гавриила научить его заповедям Божьим на том самом месте, где позднее был, воздвигнут храм в Мекке. Адам свято исполнял заповеди, за что через 2000 лет на горе Арарат вновь нашел свою жену. Адам похоронен на горе Абукаи, около Мекки...» [18, 162-163; 23, 13].

Далее Низами в том же разделе продолжает излагать историю Адама:

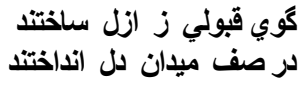

Мяч приема (у Аллаха) был сотворен изначально И брошен на ристалище сердца.

$$
\begin{aligned}
& \text { آدم نوزخمه در آمد بييش } \\
& \text { تابرد آنكوي بجوَّكان خويش بيش }
\end{aligned}
$$

Адам, новичок в игре, выступил вперед

Чтобы унести тот мяч своим чоуганом (клюшкой).

$$
\begin{aligned}
& \text { بار كيش جون عقب خوشه رفت } \\
& \text { كُوي فرو ماند و فرا كوشئه رفئ رفت }
\end{aligned}
$$

Но конь его пошел за колосьями (пшеницы),

(И) он оставил мяч беспомощным, а сам пошел в угол (ристалища)».

После раскаяния, согласно мусульманским теологическим воззрениям, Адам был признан пророком. Мастерски используя фигуру «талмих», Низами, образно выражает свои симпатии, т.е. ономастическая лексика служит раскрытию идейного содержания поэмы.

Одновременно сравнивая пророка Мухаммеда с пророком Адамом посредством поэтического средства «ташбихе тафзил» (сравнение с предпочтением), превосходство отдает Мухаммеду.

В приведенных выше двустишиях, поэт образно намекает на грехи Адама и возносит пророка Мухаммеда, который является, по мнению Низами, «инсане камил», т.е. олицетворением совершенства.

Мастерски используя традиционную стилистическую фигуру «талмих», Низами, образно выражает свои мысли и личные симпатии, т.е. ономастическая лексика служит раскрытию идейного содержания поэмы.

С другой стороны, согласно наблюдениям над функционированием антропонимов (личных имен) пророков, эти лексические единицы в тексте поэмы выступают также элементом панегирики (восхваления).

Вторым из пророков, упомянутых в «Сокровищнице тайн», выступает Ибрагим Халилуллах. Антропоним Ибрагим также является элементом восхваления. Так, например:

$$
\begin{aligned}
& \text { مهد براهيم جو راي او فتاد } \\
& \text { نيم ره آمد دو سله جاي اوفتاد }
\end{aligned}
$$

Когда Ибрахим решил (выиграть тот мяч), его паланкин.

Пройдя полпути, два-три раза свалился (с коня).

В данном бейте антропоним Ибрахим участвует в составе стилистической фигуры «талмих» и сравнения, а именно «ташбих-е тафзил» (сравнения с 
предпочтением). Предпочтение опять же отдается пророку Мухаммаду.

Ибрагим (Авраам) - прозван «Халил-ул-лах» («Друг Аллаха») - семитский пророк.

В Библии - родоначальник евреев, сын Тераха, родился в Уре (совр. Эль-Мукаяр), около 2320 г. до н.э.

В мусульманской богословской традиции Ибрагим Халил - предок бани-Исраила (израильтян) и нечистокровных арабов, первый проповедник единобожия. В Коране [(сура 39 (118); 67 (60); 123 (74); сура 96 (124); 400, 368] подробно рассказывается о его борьбе с идолопоклонством, об откровении ему веры в единого Аллаха, о его бегстве в Палестину, о его «сухуфе» («свитки») - священных текстах, связанных с его именем [12, 16-17].

\section{Materials and Methods}

По охвату глобальных проблем, среди которых смысл мироздания и человеческая жизнь, возможность гармонии между властьдержащими и народом, связь между обществом и природой, миссия и назначение индивида на земле, придаёт поэмам Низами из «Пятерицы» характер многоплановости и многоценности. Четвёртая поэма из этого цикла «Семь красавиц», явилась прогрессивной вехой как в истории художественной и эстетической мысли Востока, так и в освещении вопросов гендерного равновесия между полами. Поэтмыслитель не случайно отводит в произведении большое место женским образам, символизирующим как основные части света, так и преимущественную их мудрость в сравнении с мужскими образами поэмы.

Помимо царственных наложниц Бахрамгура, автор особо выделяет образ одной из рабынь, посвятив ей отдельную часть «Бахрам и рабыня». Идейно-художественный анализ свидетельствует о том, что в сопоставлении с другими женскими образами, способность рабыни.

Фитны сеять смуту в мыслях своего владыки, «идти против течения» ставит безвольную по статусу женщину на ступеньку выше дворцовых вельмож и наложниц.

Кто же такая Фитна? С заметной симпатией поэт описывает любимую рабыню шаха:

Вся - соблазн, имя - Смута, иначе - Фитна, Весела, очарованьем истинным полна.

При глубоком почтении этой части поэмы не ускользает от внимания приём художественной контрастности, используемый автором. Антитеза содержится уже в самом названии и содержании: шаха в положение мат поставила рабыня. На первый взгляд может показаться, что здесь повествуется о раболепной, безмолвной и простой рабыней. Веками установленные правила поведения обязывали невольницу именно к этому. Не тут-то было!

Как следует из строк, в имени женщины есть намёк на необузданность энергии, смелость в речах и поступках.

В отличие от прочих «жительниц» дворца, «прихотливая» Фитна обладала природным даром влиять на самозабвенно любящего себя шаха, побуждать его к спору и отстаиванию своей правоты.

Будучи превосходным охотником, каждого пронзённого стрелой онагра Бахрам считал чуть ли не повергнутым противником. Поэтому, упиваясь этим, он требовал от окружающих ликования, хоть и нарочитого. Когда же Фитна весьма хладнокровно отозвалась о его очередной «победе» над несчастным животным, привыкший к подобострастию Бахрам превратился в разъярённого тигра.

Видя её равнодушие даже после того «как он» копытце онагра с тонким ухом «сшил», шах решил проучить рабыню. Стойкая Фитна не дрогнула и перед уничижительной тирадой вскипевшего от злобы Бахрама, который не стеснялся в высказываниях в её адрес: «узкоглазая татарка; не видит глаз твой узкий больше ничего?» и т. д.

Антропологические данные женщины указывают на восточный генотип описанного образа. Низами Гянджеви, новатор и философ, предвидел, что Восток для человечества колыбель новых идей, научных открытий и сокровищ художественного творчества.

А Фитна продолжала «играть с судьбой» и подтрунивать над ним:

Ремесло тому нетрудно, кто постиг его.

Тут нужна одна сноровка - только и всего.

Как видим, Фитна сильна не одними «сладостными напевами». Женщина эта умела манипулировать самолюбием и моральной неустойчивостью Бахрама. Хотя и в ущерб личного благополучия, тёплому месту под солнцем, рабыня в очередной раз пытается перечить шаху.

C точки зрения гендерного равноправия мужчин и женщин, созданная литературным замыслом Низами сюжетная коллизия оказывается отправной точкой, что изменяет ход событий в пользу идейной насыщенности поэмы. Подтекст данной части демонстрирует стремление автора видеть превалирующую роль женщины в социуме, так как она источник новой жизни.

Стойкая Фитна не дрогнула и перед уничижительной тирадой вскипевшего от злобы Бахрама, который не стеснялся в высказываниях 
в её адрес: «узкоглазая татарка; не видит глаз твой узкий больше ничего?» и т. д.

Антропологические данные женщины указывают на восточный генотип описанного образа. Низами Гянджеви, новатор и философ, предвидел, что Восток для человечества колыбель новых идей, научных открытий и сокровищ художественного творчества.

Возникает противоречивый вопрос: почему расчётливая женщина в открытую конфликтует с Бахрам-гуром? Ответ на него кроется в авторской цели по созданию образа рабыни. Он выводит его за рамки будничного восприятия, расширяя понятие «прихотливая».

В широком смысле, Фитна-рабыня восстаёт против бесправия женщин и тех устоев общества, которые не обеспечивают не только равноправия, но и гармонии в социальных взаимоотношениях полов.

Развернувшиеся далее события представляют этот образ как человека будущего, способного к самоутверждению и активной деятельности в различных областях общественной жизни. Своей несговорчивостью, нежеланием потакать капризам господина Фитна поплатилась многим на целых шесть лет.

На фоне таких качеств характера приложение «рабыня» к её имени звучит диссонансно. На примере Фитни автор иллюстрирует типичность подобной линии судьбы для восточной женщины: готовность к самопожертвованию и лишениям во имя истины.

По жизни рабыня Фитна реализовала заключённый в имени смысл: посеяв смятение в другом, сама прошла через смуту и беспокойства.

Бахрам-гура она поставила в затруднительное положение: казнить или помиловать ту, которой «сладостный напев пронзает сердце»? С кем быть ему? На чью сторону склониться? Неокрепшая душа вечного любовника приняла сторону тёмных сил. И за это шаху ещё придётся поплатиться.

Позже Бахрам-гур осознаёт бессмысленность своей жизни, но печальная концовка неминуема. Он понял, что жизнь «сгорела», все чувства и желания пеплом разлетелись в безбрежных небесах. Поэт ясно даёт понять, что если властитель не отвечает своему основному предназначению, то грош ему цена. О грехе, подобно сильному онагру, бумерангом вернулась к кровожадному ловцу.

Образ Бахрама, как негативного примера прожигателя жизни, в этом плане несёт определённую воспитательную роль. Катализатором событий, которые завершились ожидаемой развязкой, стало «железная» рабыня.

Когда-то купающаяся в лучах счастья и любви женщина в трудной ситуации не сдалась, не пала духом. Тонкий ум и природное чутьё подсказали ей шахматный ход, достойный игры шахов: продолжать жить и совершенствоваться, чтобы доказать мучителю опрометчивость его решений. Она сделала всё, найдя в себе духовные и физические силы, что бы приблизить встречу с ветреным шахом.

Прожив с Бахрамом немало времени, Фитна отлично знала особенности его характера. Ещё в начале размолвки женщина почувствовала бурлящее в сердце шаха смятение, что говорило о скором раскаянии. Недаром говорят, что «в здоровом теле - здоровый дух», т. е. сильная воля и трезвые решения.

Это видно из обращения его к полководцу:

Дерзкую в живых оставлю - не найду покоя.

А убить - женоубийство дело не мужское.

Ещё, видно, не всё потеряно. Понятие чести в данном случае берёт верх над инстинктами. ОН перепоручает «чёрное» дело другому, что также обнадёживало несчастную. Теплящееся в глубине души шаха чувство души к ней и приводит Фитна в качестве одного из доводов, уговаривая старика:

Избранный и за душевный я Бахрамов друг, Всех рабынь милее я и всех супруг.

Убеждая старого вояку воздержаться от обязанности лишить её жизни, она оперирует святыми на Востоке понятиями, например: «...не хочешь горя дому своему; беды не твори; на себя крови не бери; не казни меня» и т. д.

Фитна, проявив минутную слабость, пожалела себя, сказав: «Див толкнул меня на слабость...». Но благородность конечной цели придаёт ей неиссякаемую энергию, физические и духовные. Фитна верит, что Бахрам поймёт, примет решение, изменит свою жизнь, а самое главное, повернётся лицом к многострадальному народу.

«Прихотливая» Фитна находит заветный ключик к сердцу и уму нового вершителя её судьбы. Обратите внимание, как ей удаётся постепенное установление доверительных отношений с ним. Совершенствуясь физически, Фитна в тоже время не забывала о моральной мишени: дождаться покаяния Бахрама. Недаром говорят, что «в здоровом теле - здоровый дух», т. е. сильная воля и трезвые решения.

Если основным аргументом в предстоящей дружбе было мздаимство полководца, то потом между ними возникли взаимоотношения отца и дочери. Видно, он тоже осознал цепкость ума и глубину рассудительности рабыни:

Тайный договор скрепили, жизнью поклялись; Он от зла, она от ранней гибели спаслись. 
Его также восхищала редкая целеустремлённость и трудолюбие Фитны. Ни на минуту не оставляя заботы о своём спасителе, она ежедневно тренировалась:

Женщина молодая, хоть и с малой силой, Каждый день тельца на кровлю на себе носила.

А Фитна продолжала «играть с судьбой» и подтрунивать над ним:

Ремесло тому нетрудно, кто постиг его.

Тут нужна одна сноровка - только и всего.

Как видим, Фитна сильна не одними «сладостными напевами». Женщина эта умела манипулировать самолюбием и моральной неустойчивостью Бахрама. Хотя и в ущерб личного благополучия, тёплому месту под солнцем, рабыня в очередной раз пытается перечить шаху.

С точки зрения гендерного равноправия мужчин и женщин, созданная литературным замыслом Низами сюжетная коллизия оказывается отправной точкой, что изменяет ход событий в пользу идейной насыщенности поэмы.

Подтекст данной части демонстрирует стремление автора видеть превалирующую роль женщины в социуме, так как она источник новой жизни.

Позже Бахрам-гур осознаёт бессмысленность своей жизни, но печальная концовка неминуема. Он понял, что жизнь «сгорела», все чувства и желания пеплом разлетелись в безбрежных небесах. Поэт ясно даёт понять, что если властитель не отвечает своему основному предназначению, то грош ему цена. О грехе, подобно сильному онагру, бумерангом вернулась к кровожадному ловцу. Образ Бахрама, как негативного примера прожигателя жизни, в этом плане несёт определённую воспитательную роль. Катализатором событий, которые завершились ожидаемой развязкой, стало «железная» рабыня.

Когда-то купающаяся в лучах счастья и любви женщина в трудной ситуации не сдалась, не пала духом. Тонкий ум и природное чутьё подсказали ей шахматный ход, достойный игры шахов: продолжать жить и совершенствоваться, чтобы доказать мучителю опрометчивость его решений. Она сделала всё, найдя в себе духовные и физические силы, чтобы приблизить встречу с ветреным шахом.

Совершенствуясь физически, Фитна в тоже время не забывала о моральной мишени: дождаться покаяния Бахрама. Недаром говорят, что «в здоровом теле - здоровый дух», т. е. сильная воля и трезвые решения.
Это они не могли соперничать с рабыней в смелости и ценности натуры. Именно ей удалось «раскрыть глаза» шаха на контрастность его стиля жизни и тяжёлого существования «чёрного» люда.

Вступив в брак с Луной, Бахраму удалось стать по-настоящему счастливым:

И пока не завершили долгий круг года, В наслажденье, в ласке с нею пребывал всегда.

Поэт-гражданин уготовил для своего героя справедливую кару: шах в погоне за очередной жертвой, онагром, достойных дочерей Азербайджана. Среди них жена кубинского хана, защищавшая Кубу после гибели мужа Тути-Бикя, государственный деятель Мехриджан, в течение 25 лет плечом к плечу с мужем Гачаг Наби, борющаяся за свободу народа отважная Хаджар.

\section{Conclusion}

Выдающиеся азербайджанские композиторы У.Гаджибеков, К.Караев, Ф.Амиров, Н.Аливердибеков создали замечательные образцы симфонической музыки, написали оперы и балеты, в основу которых легли поэмы классиков азербайджанской литературы и народные дастаны. Либретто и сценарии, как правило, отражают основную канву того или иного произведения, описывают чувства и жизненные коллизии действующих лиц. Нередко в хореографических постановках создается и образ самого автора, который намного сближает либретто с оригиналом. Зритель в таком случае воспринимает все происходящее на сцене, как личное, сопереживая с рассказчиком.

Автор многожанровых музыкальных шедевров Фикрет Амиров, один из знаменитых гянджинцев, начал свой творческий взлет $\mathrm{c}$ симфонической поэмы «Низами». И балетом же «Низами» был прерван его творческий путь. Этот факт весьма символичен, так как музыкальный гений композитора напоследок прозвучал его «лебединой песней», воспевшей гений поэтического слова Востока.

Создавая музыку к балету, композитор с головой «окунулся» в жизнь Низами. В этом ему помогли материалы музеев Баку и Гянджи, многодневное пребывание на родине поэта. Здесь ознакомился с экспонатами Музея-мемориала Низами, расположенного в помещении древней мечети XIX века, раскрывшими некоторые тайны мыслителя. Мавзолей великого Шейха, холодная мраморная гробница поэта навевала минорные темы будущего произведения. Исполнения фольклорного хора, представления Театра поэзии Низами, хоть и отдаленно, позволили композитору почувствовать духовную атмосферу города прошлых времен. Автору 
хореографического произведения удалось неоднократно съездить на Гей-гель, изумрудные глубины которого поведали о страшном землетрясении, погребшем город под водой.

К этой знаковой в своем творчестве работе Фикрет Амиров приступил сразу же после завершения балета «Тысяча и одна ночь». Это вполне закономерно, ибо восточные сказки Шехерезады очень напоминали вставные новеллы из поэмы «Семь красавиц». Будоражившая на протяжении долгих лет творческое воображение музыканта идея хореографического воплощения образа Низами наконец-то получила четкие контуры. Удачно складывался процесс по сбору художественного и биографического материала. Композитор разработал несколько вариантов музыкального раскрытия темы. Все это подвело композитора к стартовой черте: кое-что из уже накопленного исключалось, заменялось или трактовалось в ином русле.

Балет задумывался как музыкальнохореографический триптих, состоящий из следующих частей: «Поэт и Власть», «Поэт и Любовь», «Поэт и Лира». Планировалось использование и предыдущих симфоний: первую из них как вступление, а вторую - лейтмотивной темой. Уникальность этого хореографического произведения в его художественной многогранности. Здесь задействовано оркестровое звучание, инструментальное и вокальные соло, хореография. Композитор мастерски сочетает основные художественные средства: звучащий компонент, т.е. музыка и слово, а также хореографические движения. Тем самым автор добивается того, чтобы личность «бога» поэзии и философской мысли Востока раскрылась масштабнее, чем в случае звучания только музыки или только художественного чтения.

Сам композитор признавался, что он находится в состоянии «взлета», т.е. приступает к оркестровке сочиненной партитуры балета. Но творческая судьба композитора прервалась именно на этой стадии работы. Остановившийся творческий полет продолжил друг и соратник по цеху, композитор М.Мирзоев, завершивший написание балета.

Премьера спектакля состоялась в 1991-м году в Баку. Она начала было триумфальную судьбу балета, но опять вмешался злой рок. Партитура балета «Низами» ещё хранится в запасниках национальной музыкальной сокровищницы и ждет своего звездного часа, чтобы вновь «ожил» Фикрет Амиров и воспетый им Низами.

Как следует из наименования частей триптиха, для хореографа-постановщика предоставляется широкое поле для творчества.
Поэт мог быть воплощен и пылким влюбленным, и мудрым наставником, и творцом. В соответствии с музыкальным текстом формировалась и технически сложная хореография. Так, если поэт-юноша пребывает в состоянии «парения», окрыленности любовью, то хореографический язык предполагает каскады прыжков, вращений и выразительных па. Поэтнаставник для власть -держащих характеризуется степенностью, взвешенностью речей и движений. Здесь при сохранении академичности форм и последовательности хореографического рисунка, основные движения рук, плеч, повороты и наклоны головы отражают национальный колорит.

Поэт-создатель шедевров литературного слова, подобно парящим в небе облакам, изображен в вариации из большого количества прыжков, символизирующих мир фантазии и творчества. Они обрываются мягкими вращениями, которые сопровождает мягкая кантелена национальных движений рук. Благодаря такому решению, хореограф придает танцу поэтическую окраску, соответствующую замыслу этой части.

Уникальность этого хореографического произведения в его художественной многогранности. Здесь задействовано оркестровое звучание, инструментальное и вокальные соло, хореография. Композитор мастерски сочетает основные художественные средства: звучащий компонент, т.е. музыка и слово, а также хореографические движения. Трагическая судьба поэта- суфиста, «Данко» национальной поэзии нашла отражение в балете хореографа Н.Назировой «Насими» на музыку Ф.Амирова. Балетмейстер-постановщик, преломив сквозь призму самостоятельного хореографического мышления ставшую легендой жизнь мученика за свои идеи Насими, сумел прийти к определенному философскому обобщению. Специфичность лирикогероической поэмы в том, что романтическое начало определило стиль хореографического повествования. Используя более сложную символику, хореограф делает упор на четко обозначенные национальные мотивы. В итоге балет воспринимается как ожившие стихи поэта, характеризующиеся нетипичной образностью и художественной иносказательностью. Особой выразительностью отличается сцена казни поэтабунтаря: она основана на смене ритмического рисунка отрывка. После «дикого» танца воинов, жаждущих крови, наступает танцевальная пауза, где мерно звучат ударные в оркестре. Казалось, что это сердцебиение Насими -гражданина. Несколько напоминающая окаменелость поза ясно символизирует гражданскую непоколебимость обреченного на гибель 
человека. В этом эпизоде «геометрия» вытянутых рук страдальца, их форма и четкая визуальная «расчлененность» оставляет незабываемое впечатление.

Постановщику, актерам и исполнителю партии поэта пришлось много поработать, чтобы зритель увидел достойное личности великого поэта хореографическое воплощение. В тридцатипятиминутном спектакле Физули-актер предстает на сцене в течении 25-и секунд в начале и 30-и секунд в конце. Несмотря на это, актеру, благодаря его мастерству и проникновенности чувствами поэзии Физули, удалось решить «сверхзадачу»: показать, что жизненный пульс автора поэзии бьется в унисон с сердцебиением его героев.

Сцены Лейли с Меджнуном построены хореографом на основе полифонического танцевального развития, а «выход» старца отмечается только пластической линией изобразительно-выразительного начала.

Используя более сложную символику, хореограф делает упор на четко обозначенные национальные мотивы. В итоге балет воспринимается как ожившие стихи поэта, характеризующиеся нетипичной образностью и художественной иносказательностью. Особой выразительностью отличается сцена казни поэтабунтаря: она основана на смене ритмического рисунка отрывка. После «дикого» танца воинов, жаждущих крови, наступает танцевальная пауза, где мерно звучат ударные в оркестре. Казалось, что это сердцебиение Насими -гражданина. Несколько напоминающая окаменелость поза ясно символизирует гражданскую непоколебимость обреченного на гибель человека. В этом эпизоде «геометрия» вытянутых рук страдальца, их форма и четкая визуальная «расчлененность» оставляет незабываемое впечатление. Эффективность скульптурных поз, сочетающихся с природными данными актера, «письмо» телом придают особую величавость и изящество хореографическому облику поэта, завершая целостность его образа. Актер, являясь носителем достаточно выразительных пластических предпосылок, буквально «ворожит» движениями рук, поворотом головы и нескрываемой болью в глазах. Театральность этих мизансцен проявляется в продуманности грима и костюма, в интересной световой партитуре спектакля.
Особенно удачна цветовая гамма легкого, развевающегося балахона: ведущим является темно-серый окрас с редкими переходами в более холодный и мрачный. Ровный оклад чёрной бороды, темноватый грим, оттеняющий впалость щек истерзанного внутренними страданиями поэта, в контексте со звучащей музыкой позволил реализации пластического языка образа Физули.

Поэт-создатель шедевров литературного слова, подобно парящим в небе облакам, изображен в вариации из большого количества прыжков, символизирующих мир фантазии и творчества. Они обрываются мягкими вращениями, которые сопровождает мягкая кантелена национальных движений рук. Благодаря такому решению, хореограф придает танцу поэтическую окраску, соответствующую замыслу этой части.

Творческий союз А.Мамедова и Н.Назировой (либретто), В.Бударина (хореограф) и Т.Нариманбекова (декорации), мастерство артистов балета способствовало тому, что хореографический образ Низами воспринимался как образ поэта-гуманиста, сеятеля добра и справедливости.

В финале спектакля Физули с широкораскрытыми руками, словно гордая птица, берет под свою защиту молодых героев и взмывает с ними в небеса, символизирующие Вечность. Здесь актер превзошел даже самые технически сложные средства выражения: слегка заметным наклоном торса вперед, навстречу нуждающихся в его защите «детей», утверждает веру в добродетель. Если поэт гордой и статной поступью в начале действа подобен Мудрецу, то в финале он, Ангел-хранитель вечной Любви.

Балет является своеобразным способом мировосприятия и отшлифованной художественной формой хореографического искусства. Благодаря такому решению, хореограф придает танцу поэтическую окраску, соответствующую замыслу этой части. Его считают синтетическим видом искусства, в котором сплетаются музыка и ритм, движение и актерское мастерство, живопись и графика, пластика и декор. Все перечисленные составляющие характеризуют хореографический спектакль и расширяют его художественные возможности. 


\begin{tabular}{l|lrl|l|ll} 
& ISRA (India) & $=\mathbf{1 . 3 4 4}$ & SIS (USA) & $=\mathbf{0 . 9 1 2}$ & ICV (Poland) & $=\mathbf{6 . 6 3 0}$ \\
Impact Factor: & ISI (Dubai, UAE) $=\mathbf{0 . 8 2 9}$ & PUHU (Russia) $=\mathbf{0 . 1 7 9}$ & PIF (India) & $=\mathbf{1 . 9 4 0}$ \\
& GIF (Australia) & $\mathbf{0 . 5 6 4}$ & ESJI (KZ) & $=\mathbf{1 . 0 4 2}$ & IBI (India) & $\mathbf{4 . 2 6 0}$
\end{tabular}

\section{References:}

1. Azərbaycan etnoqrafiyası (2007): 3 cilddə, I cild, Bakı: Şərq-Qərb, 544 p.

2. Guliyeva NM, Häsänov EL (2014) Die traditionelle Gändschänischen Teppiche von Zeitraum der Aserbaidschanischen Gelehrten und Dichter Mirsä Schäfi Waseh als ethnoanthropologische quelle (XIX Jahrhundert). European Applied Sciences, 2, pp. 3-5.

3. Həsənov EL (2012) Gəncə İmamzadə türbəsi (tarixi-etnoqrafik tədqiqat). 1-ci nəşr. Bakı: Elm və təhsil, $268 \mathrm{p}$.

4. Ofəndiyev RS (1976) Azərbaycanın dekorativtətbiqi sənətləri. Bakı: İşıq.

5. Ohmədov FM (2007) Gəncənin tarix yaddaş1. Gəncə: Elm.

6. Hasanov EL (2015) Multidisciplinary approach to investigation of the basic handicraft branches of Ganja till the XX century. ISJ Theoretical \& Applied Science 1(21): 7-15. DOI: http://dx.doi.org/10.15863/TAS.2015.01.21.2

7. Hasanov EL (2015) To the Question on Research of Craftsmanship Traditions of Ganja of XIX - First Half of XX Centuries. Mediterranean Journal of Social Sciences, vol. 6, № 1, Part S1, pp. 433-437. Doi:10.5901/mjss.2015.v6n1s1p433

8. Həmidova İ (2000) Azərbaycan parça sənətinin tarixi inkişaf yolları. Elmi axtarışlar, VIII toplu, Bak1.

9. Həsənov EL (2015) Gəncə İmamzadə türbəsi ənənəvi multikulturalizm abidəsi kimi. Qafqazda mədəni-dini irsin qorunması mövzusunda beynəlxalq konfransın materialları. Bak1, 2015, p. 117-120.

10. Məmmədov FN (1976) XIX əsrdə Gəncə şəhərinin ərazisi, əhalisi və idarəsi (1868-ci ilə qədər). Azərbaycan SSR Elmlər Akademiyasının Xəbərləri (Tarix, fəlsəfə və hüquq seriyas1), №3, pp. 30-37.

11. Mustafayev A (2001) Azərbaycanda sənətkarlıq. Bakı: Altay.

12. Gadzhieva V (2015) Mesto allyuzii v poeticheskoy strukture teksta. Nizamivedenie, №5, pp. 14-19.

13. Nizami Gəncəvi (1947) Sirlər xəzinəsi. Bak1, Azərnəşr, $174 \mathrm{p}$.

14. Məmmədova MN (2012) Nizami Gəncəvi dilinin leksik üslubu (İskəndərnamə əsəri üzrə). Bak1, Nafta-Press.

15. Nizami Gəncəvi (2004) Sirlər xəzinəsi (Tərcümə edəni Xəlil Rza Ulutürk, ön söz və elmi redaktor Xəlil Yusifov) Bakı, Lider, 264 p.

16. Nizami Gəncəvi (2004) İskəndərnamə. İqbalnamə. (Zümrüd Quluzadənin ön sözü ilə) Bakı, Lider nəşriyyat, 256 p.

17. Babayev XB (1999) Nizaminin "Xəmsə"sində Quran ayələri və Qissə motivləri. Bakı, Elm.

18. Odəbiyyat-e Məzd Yəsna (1309) Yəştlər, II cild (qesmət-i əz ketab-e moqəddəs-e Avesta), Təfsir va təlif Pur Davod, Bombey, Oncomən, $408 \mathrm{p}$.

19. Nizami Gəncəvi (1947) Xosrov və Şirin. Bakı, Azərnəşr, $408 \mathrm{p}$.

20. Gasanov KN (1987) Klassicheskiy balet Azerbaydzhana. Baku.

21. Arasly N (2004) Poetika Nizami. Baku, Elm.

22. Gadzhiev A (2000) Renessansnyy mir «Khamse» Nizami Gyandzhevi. Baku, Mutardzhim.

23. Islam: Entsiklopedicheskiy slovar' (1991) Moscow: Nauka.

24. Kərimli T (2002) Nizami və tarix. Bakı, Elm. $244 \mathrm{p}$.

Эльнур Лятиф оглы Гасанов главный специалист, PhD.,

Гянджинское отделение Национальной Академии Наук Азербайджана, член-корреспондент Международной Академии теоретических и прикладных наук, Гянджа, Азербайджан 1-hasan@hotmail.com 